\title{
EDITORIALS
}

\section{FEMINISM AND THE CTS}

From its inception in 1953 women have been full participants in the College Theology Society. At a time when another national organization concerned with theology still excluded women from membership, Sister Rose Eileen, C.S.C., was among those who provided the original idea for a new organization to meet the particular needs of those teaching theology to undergraduates. The percentage of women in the membership of CTS has always been remarkable. However, in the more than twenty years of its existence, many changes have pervaded the colleges and universities where CTS members ply their trade. To take one example, the study of religion as a human phenomenon in its many manifestations has been integrated into curriculums so that our latest title, College Theology Society, expresses only part of the membership's task. If there has been such evolution in our teaching and research perspectives, it would seem inevitable that organizational changes should keep pace.

Women have always been part of the officer structure or national board of directors of the CTS. But it might be significant that none has ever served as president. Likewise, we have a committee for liaison with interest groups outside CTS on matters concerning Women and Religion but apparently no well-organized ongoing research group dialogues and/or lobbies for such issues from within the CTS.

At its most recent convention the CTS passed a resolution calling for a clear and just recognition of the growing scholarly contribution of women in the way that counts most when one gets down to brass tacks, hiring practices. Perhaps it is time CTS also got down to brass tacks.

Some have noted that women will achieve a full role in the Catholic church when society is ready for it. But it will be sad indeed if theology simply justifies with hindsight what is already acceptable. If culture and the structures of society underlie traditional attitudes toward women, a special responsibility comes to those whose task it is to analyze the development of doctrine and religious practice.

The issue of feminism cannot be simply dismissed as the peripheral concern of a special interest group. It is an issue of concern for an ever-growing number of women in the Catholic church. Feminism has come to involve what the Jewish scriptures refer to as yasha', "bringing others into an environment that is not stifling, where they can develop at ease." To dedicate one's lively efforts to such a goal for women aligns one with others who got their very names from a 
concern for yasha': Isaiah, Hosea, Joshua, and Jesus. It would indeed be ironic if contemporary women were alienated by a community that proclaims yasha:

The issues of peace and justice or liberation theology do not refer only to the developing countries or to the farms and vineyards of southern California. At times it might be convenient to speak about such issues as if we always wore specially fitted binoculars enabling us to overlook the problems of race or of class under our feet. It is in that frame of reference that we recommend the following guest editorial.

\section{-BERNARD P. PRUSAK}

\section{THE OTHER SISTERS}

This guest editorial by a member of the College Theology Society appeared as a "Letter to the Editor" in the February 7, 1976 issue of America. It is reprinted here with the permission of the editors of America. We may note that its author is also Chairperson of the Catholic Laywomen's Caucus in Springfield, Virginia.

I am one of that growing number of Catholic women who have become acutely conscious of their subordinate status in a clericallycontrolled, male-dominated church. Therefore not from any lack of interest but due instead to the various exigencies of life (I am a housewife, mother of four, full-time religion instructor at an innercity Catholic girls' high school, doctoral candidate in philosophy at Georgetown University), I was prevented from attending the ordination conference held in Detroit this past November. I have made it a point to read many of the reports about what happened there, and it was this that brought me to sharing my reflections.

There has been a general unanimity of opinion in most of what has been written about Detroit, that those preeminently concerned with securing justice for their sex in the church are the women members of religious communities. I would seriously doubt this to be true. What is true is that these women, although a numerically small segment of the American church's female members, have nationaleven international-organization, have penetrated to some degree the church's clerical circles and, of these, a few have managed to make themselves highly visible and vocal on this particular issue. The Catholic laywoman on the other hand, is not part of such a network, has no need for such organization, and, as a result, her allegiance and missionary effort is directed toward the church's local presence, the parish. There are laywomen speaking out against the injustice perpetrated against them by the male members of the Christian community, but these are only being heard within the limits of local jurisdic- 